\title{
A Critical Reading of A. J. Arberry's Translation (*) of the Meanings of the Holy Quran (Koran Translated)
}

\author{
Ahmed Gumaa Siddeik* \\ Former Head of English Department, AL-Zeem Al-Azhri University-Sudan, P.O.Box 18 - Dawadami, Shaqra \\ University - KSA 11911, Saudi Arabia
}

*Corresponding Author: Ahmed Gumaa Siddeik, Former Head of English Department, AL-Zeem AlAzhri University-Sudan, P.O.Box 18 -Dawadami, Shaqra University - KSA 11911, Saudi Arabia

\begin{abstract}
This is a translation of a paper originally written in Arabic about the well known translation of the Holy Quran by A. J. Arberry, who gave it the title of (Koran Translated). The author, Dr. Haithm Saab, a language professor, showed great interest in Arberry's work as he believed that it was and still is one of the best translation made by a non-Muslim scholar in English, of the Holy Quran. The paper covered many aspects of the translation and came out with valuable recommendations. My translation to this paper is to complete the role of the original author's work, to address another group of audience in their own English language. The author was able to clarify some linguistic and technical points about Arberry's translation; and he made corrections of some errors which were/are-intentionally or unintentionally made by the translator. The author handled the topic with professional skills to explain where Arberry erred and he made suggestions that can add great value to A.J.Arberry's original translation (Koran Translated) which was published by Oxford University Press in 1964.
\end{abstract}

Keywords: Islam - Arberry- Quran - translation- distortion-orientalism - errors

\section{INTRODUCTION}

The interest in the translation of Islamic Studies and the meanings of the Holy Quran from its Arabic origin, into the various languages of the earth, is occupying a large place, in the Islamic field in general and in the Quranic studies in particular. It has become the interest of the individual persons, related centres and institutions all over the world. These translations are of great importance because they are a double-edged weapon. As on one hand, they may have a significant impact on the CALL to (Allah), to spread Islam, bringing Muslim and non-Muslim from English speakers, to read the Book of God, and on the other hand this translation can be negatively used as tools of distortions and hostile ideas against Islam.

For example, the Jewish Zionists recently issued a distorted translation of the Holy Quran into Hebrew in order to harm Muslims and hurt their feelings as well as spreading distorted ideas about the Islamic religion. This behaviour called on Muslims to move to work and produce a correct translation of the Quran into this language. The Azhar University led this project. This Hebrew version of the Quran translation has shown us the grave danger of misusing the Quranic translations, and negatively exploiting them for personal agendas.

This blessed symposium, which is being held by King Fahad Complex for the Printing of the Holy Quran, in the city of the Messenger of Allah (peace and blessings of Allah be upon him), is a great opportunity to shed light on some great efforts exerted in this great field, namely the translation of the meanings of the Holy Quran into foreign languages.

In this great scientific forum, researchers and specialists in this field, will need to meet to study and analyze translations of all kinds, to learn about their pros and cons, and know how to exploit these translations for the interest of Islam and Muslims. These scholars will need to work on what would serve the Book of God and defend Islamic beliefs against the enemies of this nation.

And due to the high status and due to the great popularity of this English language in these modern times, in this 21st century; the English translations of the meanings of the Qur'an have taken the lead among all translations in other foreign languages. 
Now, we can see from time to time, the emergence of a new translation of the meanings of the Quran in this English language. This requires efforts of all Muslim scholars to immediately study and analyze these translations to determine its validity, and its accuracy in conveying the meanings of the Quran, to millions of people who speak this language; which is only second to the Chinese language in terms of the number of speakers, all over the world. It may even be at the forefront of all languages, toady, in terms of its political, economic and educational importance all over the globe.

In the past, the English translations of the Holy Quran had been misused, because those old translations, from the beginning of the first translation in the seventeenth century, to the end of the nineteenth century, were prepared by a handful of English priests and Orientalists including Wherry, George Sale, Rodwell, and Palmer. The majority of those translations were made by antagonists who espoused hostility to Islam. The aim of their translations was originally to attack Islam by claiming contradiction and ambiguity in the verses of the Quran, as well as questioning the Quran as being the word of God.

It was therefore not surprising that the title of the first English translation made by an English writer (Alexander Ross) in 1649, had been translated from the French Version and entitled: (Alcoran of Mahomet). Ross said in his long title that his translation aimed at satisfying the wishes of everyone who wanted to look at the idols of the Turks (Muslims, of course), asserting that his basic claim that the Quran had nothing to attract Christians, and therefore was not risky to read. ${ }^{(1)}$

Thus, these translations did not provide any service to the people of Islam, due to their hostile positions, with clear declared goals, or due to the loss of the linguistic aspect, in term of accuracy and clarity, as those translations were full of mistakes-intentionally or unintentionally-made; and the result was a distorted work that did not serve the translations of the meanings of the Holy Quran in any way.

On the other hand, Muslim scholars did not begin translating the meanings of the Quran into English until the beginning of the twentieth century, with Abdul Halim Khan's translation in (1905) and Marmaduke Pickthall's translation in (1930), who was the first English Muslim to translate the Quran. In addition to Yusuf Ali's well known translation in (1934), which was different in its orientations and objectives from other previous non-Islamic translation, but it was as well not without linguistic errors of course. But Muslims to be late in translating the Quran until modern times, may have had a negative impact on the process of correcting the distorted images of Islam and Muslims, which had been transmitted to the minds of the Western people through Oriental translations of the Holy Quran over many years.

\section{BACKGROUND}

\subsection{The Translation of Arthur J. Arberry, In Brief - His Writings and Views on the Quran}

The recent translation is really of a special kind. It is completely different from its predecessors in terms of orientation and purpose; because it has a side of fairness to the Holy Quran, as the translator was defending and drawing attention to ability of communication of the Holy Quran, the power of its words, in addition to its splendour style; although the writer, Arthur J. Arberry, was a non-Muslim Orientalist. He was an English scholar, who in 1964 made the latest English translation of highquality of the meanings of the Quran and called the title: (the Koran Translated). It appears that this translation was not well studied and analysed from interested Muslim scholars and researchers despite its fame in the West and despite its scientific authenticity in terms of accuracy in translation. So we will try in this research, to study this translation in all aspects and will focus on some defects and errors made by the translator.

Arthur John Arberry (1905-1969), orientalist, was born at Buckland, Portsmouth, on 12 May 1905. He attended Portsmouth Grammar School, and entered Pembroke College, Cambridge, in 1924, where he studied classics and oriental languages. He was head of the Classics Department at Cairo University from 1932 to 1934. He became assistant librarian, in India Office, London from1934 to 1939. Then he worked in the Ministry of Information from 193 to 1944, and thereafter became Professor of Persian Language and of Arabic (1946) at London University in (1944). In 1947 he was appointed Professor of Arabic at Cambridge University. Arberry published over sixty works, in addition to his translation

(1)Naji Oueijan, The Progress of an image: the East in English Literature, (Peter Lang: New York, 1996), p. 21. 
of the Koran in (1935). He died in Cambridge on 2 October 1969.

He was passionate about Persian literature; as he was active in writing in the literature of the East. In addition to translating the meanings of the Holy Quran, he wrote more than sixty works on various topics on the comparison of Arabic and Persian religions and literature. The most important of his works were:

1. The Manifestations of Islamic Civilization and its Portrayal in the Original Texts.

2. Fifty Poems of Hafiz.

3. Discourses of Rumi Sermons.

4. Poems of al-Mutanabbi: A Selection with Introduction, Translations \& Notes.

5. Revelation \& Reason in Islam.

6. Religion in the Middle East (in two volumes). (for further detail see brief history in Wikipedia)

This brief history showed the man's knowledge of Arabic literature and Arabic language. Arthur J. Arberry was one of the few Orientalists who had positive attitudes towards Islam and the Quran. He was different from the others for his objective view and his emphasis in fairly judging the Quran as expressed in his great admiration for it. And instead of starting his translation by attacking Islam and slandering the Quran, as it was customary among the Western Orientalists, Arberry began by realizing that this Quran was miraculous and untranslatable, so he chose the title to be "Koran translated".

But despite all his efforts, Arberry was not able to get all the truth about the Quran, but he confirmed his belief that the Quran represented a literary masterpiece unparalleled in its literature of the whole world. He saw that it was neither poetry nor prose in itself, but a combination of the two types. $\mathrm{He}$ believed that the eloquence of the Quran, its miraculousness and its splendor, its greatness which as similar as the oceans, was all blocked, to be unseen by some other oriental critics, who had been confused by their great ambition to explore the Quran, with limited rigid rules. He described those critics in a beautiful literary language and expressed his contempt for them as (...bewildered critics ambitious to measure the ocean of prophetic eloquence with the thimble of pedestrian analysis ${ }^{(2)}$.

Arberry began his journey with the Holy Quran by choosing a number of Verses. He studied them, translated them into groups and classified them according to their subjects and sometimes according to the causes of revelation. In his introduction to this experimental translation, Arberry stated that, if the readers accepted this work, he would translate the entire Quran, relying on readers' assessments, observations and their guidance.

In the introduction, Arberry defended the Holy Qur'an, its eloquence, its power of expression and the beauty of its style-against the fabrications of some Orientalists, notably Thomas Carlyle who described the reading of Quran as "...toilsome reading as I ever undertook, a wearisome, confused jumble, crude, incondite. Nothing but a sense of duty could carry any European through the Koran." (See Arberry's introduction). So Arberry brutally branded Carlyle for his inability of tasting the Quran eloquence and accused him for lack of understanding the Quranic texts.

Although Arberry did not believe that the Quran was the word of God, but it was the work of a supernatural power, but he proved the invalidity of the claim of the Orientalists (such as Margoliouth and Gibb) that the Quran was the words of Muhammad; and it seemed that Arberry directed his experimental translation to address Muslims, specially the Europeans among them. But his goal as he stated, (...only here I am trying to show what the Koran means to the unquestioning soul of the Believer...(3). So he was keen to try to show the truth of the Quran to the believers who were not diligent.

Arberry claimed that the greatest achievement in his translation was his invention of Rhythmic Patterns in the English translation similar to what was in the Quran. He said that he discovered this feature unlike any of all his predecessors of translators, as he tried to simulate the Quranic rhythm. In this paper we will highlight this important aspect in his translation.

(2)Arthur Arberry, The Koran Interpreted, (Oxford: Oxford UP, 1964), introduction, xi..

(3)Arthur Arberry, The Holy Koran: An Introduction with Selections, (London: George Allen and Unwin Ltd, 1953), introduction p.31. 


\section{THE MERITS OF ARBERRY'S TRANSLATION}

There is no doubt that such an English translator who was holding such positive, fair positions and views on the Holy Quran; and at the same time had good taste for the beauty of the language of the Quran, its eloquence, its strength of expression and the style of its language; such a man with such admiration, would of course use the language that suited the greatness of this miraculous religious texts, which was not human-made as he confessed in his introduction.

Therefore, Arberry's translation was generally strong in its language, which was distinguished by its literary characteristics, in using clear language that corresponded to the eloquence of the Book of God; in his attempts to simulate this method, which he described as the sublime rhetoric of the Koran. He combined between eloquence and rhetoric on one hand and simplicity and clarity on the other hand. But despite all those efforts, we could not negate the occurrence of some linguistic errors of all types. But it is important to highlight the bright aspects of his translation, which are closely linked to his views on the eloquence of the Quran.

\subsection{Firstly: The Accuracy in Conveying the Meanings of the Holy Quran}

Arberry questioned the accuracy of his translation and was careful not to use any explanatory comments or detailed annotations; as such comments do and did not exist in the Quran itself and that would lead to disturb the fresh flow of the Quranic text. This technique indicated his integrity in translation. He was desirous to completely convey the meaning of the words of the Quran without deficiency or increment.

\subsubsection{Some beautiful models of accuracy in the translation}

These examples include:

1. His good and accurate understanding of the meaning of the word [واذ حر] as it appears in the Quran:

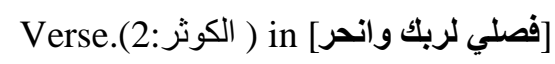

He was successful to translate it correctly as: (so pray unto thy Lord and sacrifice). Unlike other Orientalists who translated the meanings of the Quran, such as Rodwell, who distorted the meaning of the verse by translating it as: (Kill the victims) and this translation might indicate the slag of the translator in the distortion of the meaning.

2.In the translation of [ بعضكم لبعض عدو] in (al-Baqarah: 36), Arberry used a precise expression in a beautiful manner, in the sense of "each of you an enemy of each"

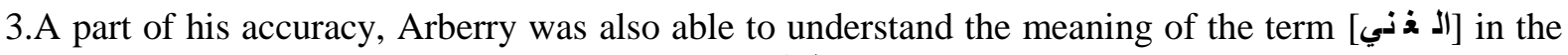

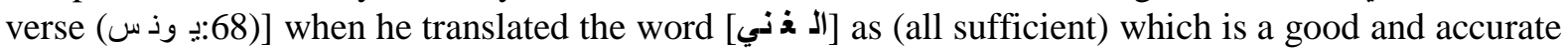
translation, unlike Hilali and Khan's, despite their use of explanatory comments, they translated the word as (rich- ال iغني) which means (free of all needs). Arberry's translation to the term was even better than Peckthal translations who translated the word as: (He hath no needs).

4.Arberry's translation of [إن مكناهم في الأرض] in (Al-Hajj: 41) went as follows: (If We establish them in the land); it is an accurate and concise translation that fulfils the meaning of "empowerment" in the verse without the need for further clarification or commentary, as in some other translations.

\subsubsection{The accuracy in conveying the meanings of some of the Quranic terms and meaning}

On the other hand, Arberry also demonstrated the understanding of the Quranic (idioms) and translated them very well, unlike some of those who have resorted to literal translation. Some of these idioms are following:

\section{[ثاني عطفه ليضل عن سبيل الله][(الحج:8).1}

As (turning his side to lead astray from God's way)

2. He translated it as:

(He turns completely over). This translation was more accurate than Hilali and Khan's who translated it as:(He turns back on his face). 


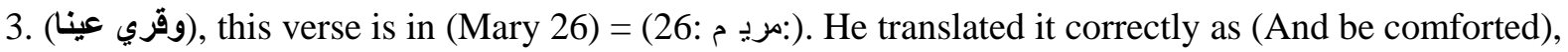
where others did a wrong translation as saying (and cool thine eyes).

4. But in the translation of this Quranic metaphor: (الاحز اب:10), Arberry did not present the correct synonym in English, as it was meant to describe the intensity of fear and panic, it was better to use the English expression that corresponded to this Quranic expression in meaning to read: (And your hearts were in your mouths)

5. Arberry had a good understanding of the meaning of

(Altaghabun:4 in verse) والله عليم بذات الصدور\}

He translated it as:( And God knows the thoughts in the breasts.) He chose the word (thought) which was a suitable choice to convey the intended meaning

6. $\mathrm{H}$ was successful in his translation of:

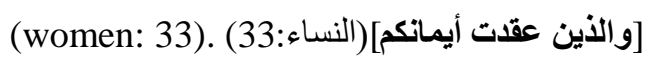

As he translated it as (and those with whom you have sworn compact). He was also correct to convey the meaning of:

$$
\text { (37: (النورن }
$$

The meaning of this verse is also accurately and clearly rendered as: (They fear a day when the hearts and the eyes are different) in verse (the light:37), unlike other translators, who translated it as: (fearing a day when hearts and eyes will be turned about.)

7. Arberry showed high competence in commanding the details of Arabic. We can see his craftsmanship in the translation of the following verse:

$$
\text { [أعرض ونأى بجانبه] (الإسراء:83 ) }
$$

He translated it as (he turns away, and withdraws aside).The translation is good and accurate as it means the person in question refrained from thanking God as a sign of self pride $\left(^{4}\right)$.

\subsection{Secondly: High literary language}

It is rare for a translator of the meanings of the Quran to simultaneously combine precision and clarity of style and power of the phrase. This is not easy, and by looking at Arberry's translation, the reader would feel his relentless effort to reach this goal. It was clear that Arberry tried very hard to improve the translation style to approach the language of the Book; which he believed an absolute literary masterpiece that had no parallel in any other language. Therefore, Arberry wanted to make his translation distinctly fine, by using literary style, as well as trying to use literary words, as alternative to general terms, that were usually ineffective and disproportionate, compared with the fluency of the Quran.

Here are some examples of the formal expressions used by Arberry

1. The use of the word sorcery instead of magic in the sense of "magic".

2. The use of the word extirpate in the sense of "go in your way" rather than overcome in the verse "Go in your best way"

$$
\text { (Taha: 63)[ويذهبا بطريقتكم المثلى] in (63:) }
$$

3. The use of the word fashioned and it gives better meaning than the common word made in the translation of the words.

Then he translated

[تلقف ما صنعوا] (طه:69)

As (it shall swallow what they have fashioned).The meaning of this verse has been accurately translated.

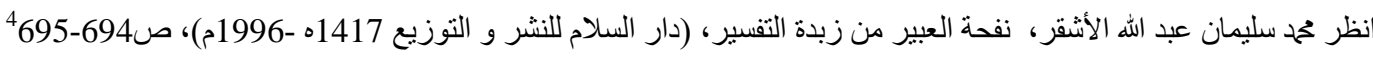


4. The use of the word alight in the sense of "anger befall on you" in the verse: (Taha: 86), instead of using the word descend as used in the translation of Abdullah Yusuf Ali and Halali \& Khan.

5. The use of the term guile meaning (plot) in the verse

[فأجمعو اكيدكم] (64:)

6. In the translation of the verse:

$$
\text { [وإيساي فار هبون] (البقرة:40) }
$$

He used the expression of 'have awe of me' which is more eloquent and conveys the meaning than "dread "الرهبة: which means "fear none but me".

7. The use of the word surmise which literary expresses the word "suspicion" in the verse

$$
\text { (women: 157)- (النهم به من علم إلا اتباع الظن] (النساء:157) }
$$

\section{Examples of the literary terms used by Arberry:}

1. Arberry used very literary expressions, as in the translation of the meaning of ...

$$
\text { [قد شففها حباً] (يوسف: 30). }
$$

Which is (She has a passion for love) in (Yusuf: 30).

Arberry translated it as (smote her heart with love.).

As well as excelling in the translation of the meaning of:

$$
\text { [الذي جعل لكم الأرض فراشاو السماء بناءً] (البقرة:22). }
$$

(Who made the land for you as bed and the heavens as cover) in (al-Baqarah: 22). He translated it as (who assigned to you the earth for a couch, and heaven for an edifice.)

2. He used the literary word cast - which is more expressive in verse:

$$
\text { [قالو ايا موسى إما أن تلقي] (الأعر اف: 115) }
$$

Rather than the use of (throw) as in most translations of Pickthall, Abdullah Yusuf Ali and Hilali \& Khan.

3. He used the following literary words: nigh meaning "close" and slay meaning "kills" and ungodly meaning "slackers" as well as vanity meaning "falsehood" in the verse:

$$
\text { [و لا تلبسو ا الحـق بالبـاطل] (البقرة:42) }
$$

(You should not wear the right falsehood) (Cow: 42). He translated it into:(And do not confound the truth with vanity.)

In the translation of the meaning of the meaning of:

(الحجر No space \{lone:60) (انهما لمن الغابرين\}

(It is for those who are alienated). He used the following translation: (She will certainly be of that tarry) and the word tarry is a beautiful literary expression and meaningful. This translation is better than (She will certainly be of those who remain behind.) as translated by others.

4. Arberry used the phrase (wax insolent) expression to accurately translate the word "dominate" instead of becoming (arrogant).

5. He used a beautiful expression in the translation of:

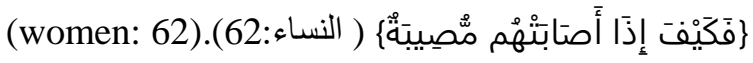

(When if the disaster hit them). He translated it as:(When they are visited by an affliction.)

6. In the translation of the meaning of

$$
\text { [يومئذ يصدر الناس أنتناتاً] (الزلزلة: 6) }
$$


Arberry used the literary word (issue) to completely fit the meaning of (يصدر) as in the verse.

7. He used the word sojourn, which is literary in the sense of "dwelling" or "stable", in its translation of the meaning of the verse:

$$
\text { ( البقرة:36) :-) (لكم في الأرض مستقر] (Al Baqarah 36 ] }
$$

That is "You are in the earth stable".

\subsection{Thirdly: The Attitudes of Arberry Towards the Holy Quran}

Anyone who reads this translation will notice that it is free of distortion of Islam, or interpretation that would challenge the Holy Quran or abuse the person of the Prophet (peace and blessings of Allah be upon him). And what could confirm the integrity of Arberry's translation that his translation was free of any offensive words to the Quran, or to the Islam or to the person of the Prophet (peace be upon him). The translation is also free of any footnotes.

\subsection{Fourthly: Translation of the Word Allah the Majesty}

The word "God" is used to mean the word "Allah" in all translations. The word "God" is not used by many non-Muslim English speakers. The word "God" is the common word for the meaning of divinity in all English speakers. The use of the word "Allah" may cause some confusion and misperception among many non-Muslim readers of the translations that would make the word "Allah" as if it is "the God of the Arabs only".

\subsection{The Claim of Trying to Divide the Quranic Verses in the Form of Rhythmic Pattern}

Although most of the readers of this translation assert that the most distinctive characteristic of the translation of the language of Arberry was the fluency of language and the sweetness and the beauty of style, but Arberry himself claimed that he invented a new aspect in his translation of the (Koran) that did not come from the previous translators in any language. This discovery concerned the side of the language itself as it related to the rhythmic aspect of the verses of the Quran. He said in his introduction, "I have striven to devise rhythmic patterns and sequence-groupings in correspondence with what the Arabic presents, paragraphing the grouped sequences as they seem to form original units of revelation. ${ }^{(5)}$

There is no doubt that this statement was one of Arberry's fallacies and represented a major imbalance in his understanding, because he mistakenly believed in his ability to simulate the rhythm of the sound in the Quranic verse, when he imagined that he could write a translation that seemed to be in harmony, to make the Quran, as if it was revealed in English. The reader of this translation will see the existence of some of these patterns in this translation such as the division of most verses of the Quran into lines similar to verses of poetry, but the question arises is: Could Arberry really keep up with the rhythm of sound in the Koran?

Firstly: To arrive at these patterns, in his first experience of the translation, Arberry selected some verses to study the rhythm in the Quran, such as long verses of divorce in (Surat al-Baqarah) and short ones (such as al-Qarayah, al-Fathah and al-Fath). He concluded that this was the basis for the division of the words of the Quran into short and long syllables.

Secondly: He believed that the sound in the Quran was often based on two types of sounds: the first one is called dactyl with one stressed syllable followed by two unstressed syllables and the second one is called iambic which is unstressed syllable followed by stressed one. These as he said were the most common sounds in the Quran.

If we look at the first verses in Sura Al-Qaria (the Clatterer), we will come to find that Arberry tried to choose the words in the English translation to be perfectly identical-in length and place of the syllable and also in the occurrence of the tone or non-words in the Quranic text. Here is an example in Latin letters with the corresponding translation:

The Clatterer! What is the Clatterer?

Al-qūri 'a : mā l-qāri 'a

And what shall teach thee what is the Clatterer? wa-mā adrāk mā l-qūri 'a

\footnotetext{
${ }^{5}$ Arberry, The Koran Interpreted, introduction, $\mathrm{X}$
} 
We note that perhaps the rhythm was applied in the first line (in the first and second verses), while he did not succeed in applying it on the second line,

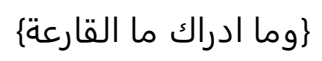

This does not match the rhythm in the Quranic text. This simple example may lead us to conclude that Arberry could not apply his theory on the rhythm of the sound in his translation of the meanings of the Holy Quran,

This is what he exactly said that the study of this aspect in detail, in a systematic and accurate manner, was necessary for all the texts of the Quran before reaching any results, but this is/was not easy despite his belief in the importance of this neglected side, which was not preceded by anyone.

Arberry's failure to deduce a particular pattern of what he called the rhythmic patterns in the Quran, and his inability to imitate some of these aspects, is a powerful proof that the Quran as a Book of God, is miraculous and eloquent. It is beyond the limited abilities of human beings. Arberry was in great hurry to claim that the successive paragraphs in his translation might seem as an inspiration or a revelation by God.

\section{THE LINGUISTIC ERRORS}

Although Arberry's translation outperformed many other translations in terms of accuracy in meaning, clarity of language and simplicity of style; the occurrence of repeated errors was inevitable, especially those linguistic errors that occurred due to the fact that the translator was genuinely not Arab, so he might misunderstand the meaning of a certain word or phrase in its literal sense, or he might not realize the meaning of some of the Quranic expressions as it happened with many translators, non-Muslims or even native speakers of Arabic.

Errors might have been due to confusion of words, that a translator used a word somewhere instead of another. But this does not diminish the importance of this translation and its prestige among other ones.

In the following section, we will try to highlight some weaknesses of Arberry's translation. We will detect some of the most important examples of mistakes that he made.

\subsection{First: Errors in understanding the semantic meaning of some of the words of the Quran}

1. Arberry made a mistake in the translation of the meaning of the verse:

$$
\text { [إلا بثق الأنفس] (النحل::7) }
$$

He translated it as (expecting with great distress) but distress in this sense is a "psychological pain" or "sadness". So it does not fit the meaning, so it was better to say: (with great effort).

Arberry erred in Surat Resurrection (31-35) and did not succeed in translating its linguistic and semantic meaning as well as its grammatical aspects. The meanings of some words and expressions were not clear to him as in the following verses:

$$
\text { (القيامة:31-35) [فلا صدّق ولا صلى ولكن كذّب وتولى ثم ذهب إلى أهله يتمطى أولى للك فأولى ثم أولى للك فأولى] }
$$

He translated it as (For he confirmed it not, and did not pray, but he cried it lies, and he turned away, then he went to his household arrogantly. Nearer to thee and nearer, then nearer to thee and nearer.)

It should have been translates as:(And so he neither believed nor prayed, but he disbelieved and turned away, then he stalked to his household in full conceit. Woe to thee, and then woe to thee.

$$
\text { [فتاب عليه إنه هو التواب الرحيم] (البقرة:37] }
$$

2. In (Al-Baqarah: 37) Arberry was unable to convey the meaning of "repented" into English in this context and resorted to repeated words, he said: (and He turned towards him; truly He turns, and is All-compassionate). This translation means that, "God accepted him, that God accepted and he is merciful". This translation is not accurate in meaning and with thinness of style, He would better say: (and He pardoned him. Truly He is the Most Forgiving, the Most Merciful.)

3. He also made a wrong translation of:

$$
\text { [ثم تاب الله عليهم] (المائدة:71) }
$$

He put it as (Then God turned towards them). It should have been translated as (Then God repented to them) (al-Maida: 71) 
5. He did not succeed in translating (الأمر بالمعروف) as he put is "honor" and (النهي عن المنكر) as he put it "shame". But both words do not carry the correct meaning. So it was better if he translated the terms as: (bid to good and forbid evil).

6. He was also wrong to translate:

Into (We turn about the signs) and should have been translated as (We explain the verses variously).

7. He made a mistake in translating:

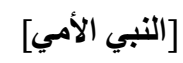

as (The Prophet of the common folk), while the correct translation is: (The Prophet who is illiterate)

8. He made a Wrong translation of:

$$
\text { [خذ العفو] (الأعراف:199) }
$$

He put it as: (Take the abundance) while the correct translation is: (show forgiveness.)

9. Arberry failed to convey the Quranic meaning of:

$$
\text { [قلن حاش الله] [يوسف:31) }
$$

In (Joseph: 31) as using: (God save us!), while the nearest English expression is: (God forbid)!

10. He did not understand the meaning of :

$$
\text { [ولا نضيع أجر المحسنين] (يوسف:56) }
$$

As he used the word "wage" which means "financial remuneration" But he should have used the word (reward) in this context.

11. He made a wrong translation for:

$$
\text { [نجمع عظامه] (القيامة:3) }
$$

As he put as (gather his bones), while the correct translation is (assemble his bones).

12. He also translated the word (الآخرة) as (the world to come), while he could have used the word (the hereafter).

13. He translated the verb (worship يـ ع بـ:) as (serve), and the word (slave inaccurate; as the meaning of (serve) in Webster is: (To render obedience or homage to (God or sovereign) ${ }^{6}$. But this does not necessarily indicate that the meaning of worship as much attesting to obedience and respect, so it is best to use the word: (worship), because it is more accurate in the Quranic context.

14. He did not succeed in choosing the appropriate word for the verb: قطع:) (يـ

$$
\text { [ويقطعون ما أمر الله به أن يوصل] (البقرة: 27) }
$$

Arberry translated the verse as:(Cut what God has commanded should be joined). Perhaps this is contrary to Arberry superior style in dealing with words and expressions. The fluent word in English in this sense was (sever) in this context.

15. He used the literal translation of the verse:

$$
\text { [إن الله لا يستحي أن يضرب مثلاًً (البقرة:26) }
$$

in (AlBaqarah: 26) that (God is not ashamed to strike a similitude). It is an inappropriate translation in style. Perhaps the best translation is:(God disdains not to set forth a similitude).

\subsection{Second: Grammatical Errors}

Arberry fell into the error of omission and sometimes adding some words and grammatical words in the verses. Examples of deletions included the first verses,

\section{[يا قوم] (هود)}

1. He translated it as (O my people). It should have been translated as (And O my people). As well as his translation of:

\footnotetext{
${ }^{6}$ Webster's Encyclopedic Unabridged Dictionary of the English Language. (Gramercy Books: New York, 1989) 
(Seek you help in patience and prayer). He should have added to read (And Seek you help in patience and prayer.)

He sometimes mixed between (and) and (also) at the beginning of the verseas in the translation of:

$$
\text { [ وقال يا بني لا تدخلوا] (يوسف:67) }
$$

"O my son, do not enter into it" (Yusuf: 67)

Where he used the word (also) instead of (and) in his translation.Sometimes Arberry deleted the second pronoun (you) in English in many verses that contained an appeal, such as:

$$
\text { [يا أيها الذين آمنوا] }
$$

He translated it as (O believers) instead of ( $O$ you who believe). In others, he deleted the $(\mathrm{O})$, as the verse:

$$
\text { ] يوسف أيها الصديق] (يوسف:46)(Joseph, thou true man) }
$$

It should be translated as (O, Joseph, thou true man).

2. And in the verse:

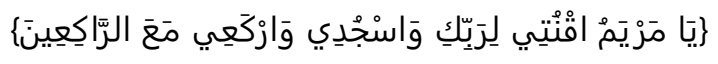

Arberry translated as (Mary, be obedient to thy Lord, prostrating and bowing before Him) in (AlImran: 43). He deleted (with those who bow down-مع الر اكعين) as well as dismissing) O=الي).

3. He deleted the preposition (on) or (whereon) in the translation of:

$$
\text { (ويوم نحشر هم) (ونس:28) }
$$

Where he translated it as (And the day We shall muster them) while he could say (And on the Day We shall muster them).

4.In the English translation, he deleted the word "make" in the translation:

$$
\text { (لا تفسدوا في الأرض) (البقرة:11) }
$$

(Do not corruption in the land)-(al-Baqarah: 11).

The sentence became grammatically wrong. Perhaps the word (make) fell due to a typographical error!

He also committed a mistake by adding words not included in the Quranic text as:

(يوسف:[آيات للسائلين]) (signs for those who ask (questions)

Where the word questions is not in the verse.

Arberry also changed the meaning of the verse

( ولا يحسبن الذين كفروا سبقوا إنهم لا يعجزون)( الأنفال:59).

He translated it as (And thou art not to suppose that they who disbelieve have outstripped Me; they cannot frustrate My will.) where he added (Me) and (my will) although they are not in the original text. As well as changing the pronoun in (يحسبن) as (they suppose) to (يحسبن) to read as (thou art).

Arberry made many other grammatical mistakes in using verbs, pronouns and other grammatical structures.

He always translated (يصبح) in:

$$
\text { [فأصبح يقلب كفيه] }
$$

As (and in the morning he was wringing his hands). But the meaning of ( يصبح=يصير is turn into), so the correct translation should be(and he began wringing his hands). 
Arberry sometimes mixed between the passive tense and the active tense. The coming is a good example for this. He was not able to distinguish between (يقاتكلون) و(يقاتلّون)as in:

$$
\text { ( أذن للنين يقاتكون بأنهم ظلموا)(الحج:39) }
$$

because he translated it as (Leave is given to those who fight), while the correct translation is (Leave is

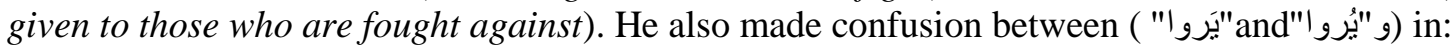

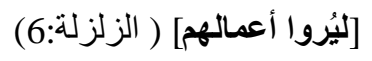

He translated it as (to see their works), while the correct translation is (to be shown their deeds).Therefore, it is clear that Arberry found it difficult to translate the structure of the Passive in Quran and sometimes missed to differentiate between the active and the passive voice. He also used a static and incomprehensible approach to translate:

$$
\text { [إن شكرتم وآمنتم] ( لنساء:147) }
$$

He put it as (if you are thankful, and believe), and the error here is that he did not match the words ("شكرنم" و"آمنتم")

"thank you" and "believe" in their grammatical formulas. He combined between an adjective (thankful) and a verb (believe), and the fact that the use of the formula of the verb is more obvious in this case: if you (thank) and (believe) (Him).

$$
\text { (الذين آتيناهم الكتاب يعرفونه كما يعرفون أبناءهم) ( البقرة:146) }
$$

He returned the pronoun in (يعرفونه) to the Book as he put (Those to whom We have given the Book recognize it as they recognize their sons). But the correct form is (Those to whom We have given the Book recognize him as they recognize their sons), as (him) here refers to the prophet (peace be upon him) and not to the Book.

It is strange that Montgomery Watt, the English orientalist wrote an explanatory guide to the words and terminology of the Quran based on the translation of Arberry. He referred to the grammatical possibility that the pronoun in this verse can also refer to the prophet (peace be upon him), as he puts it that (... recognize it: the Book; 'him' is grammatically possible, and would refer to Muhammad $^{(7)}$. But perhaps there was no coordination between Arberry and Watt regarding this Manual, especially if we take into account the hostile and well known attitudes of Watt against Islam, the Quran, and the Prophet (peace and blessings of Allah be upon him), where his distortions appeared in this Manual and in his other books.

Arberry mixed between:

a (و لام العلة=and (require as in the verse:

$$
\text { [ربنا ليضلّوا عن سبيلك] ( يونس:88) }
$$

Where he translated it as (Our Lord, let them go astray from thy way), while the correct translation should go like this (Our Lord, that they may lead astray from thy way). It does not mean request for humiliation, but it means the result and the consequences of what God granted to Pharaoh and his people was to compromise the path of God.

It seemed that Arberry used the exclamation mark incorrectly in some verses, for example he used it instead of the conditional case in the following translation:

$$
\text { [ [ [ن كنتم تعلمون]: }
$$

As he translated it (Did you but know?), where it should be (If you but know)

He made an incorrect translation of:"النفس اللوامة

As he translated it as (the reproaching soul), which may mean "self blame". He would better to say (The self-reproaching soul).

(7) W. Montgomery Watt, Companion to the Quran: Based on the Arberry Translation, (London: George Allen and Unwin Ltd, 1967), p.81. 


\subsection{Third side: The Repetition of words}

Aiming to precision, led Arberry to some problems. He was too little to make some exaggerations on that in certain cases. Aiming to be accurate; the translation of some words were repeated in some verses for example:

$$
\text { [ولما جهزهم بجهاز هم] (يوسف:59) }
$$

He translated it as (When he had equipped them with their equipment). Another example is:

$$
\text { [وعليه فليتوكل المتوكلون] (يوسف:67) }
$$

(Let all put their trust who put their trust). And this one is a bad translation and also unclear in style.

And also in the verse:

$$
\text { [وقل رب أنزلني منزلاً مباركَّا وأنت خير المنزلين] ( المؤمنون:29) }
$$

In his translation of the meaning of this verse in (Believers: 29), he repeated the word harbor three times to correspond to the repetition in the root of the word (نزل), as follows:

(And say, "O my Lord, do Thou harbor me in a blessed harbor, for Thou art the best of harbourers)

Thus, the translation lost eloquence and effectiveness to cope with the repetition in the original text; although repetition is one feature of the Arabic language, for the purpose of confirming the idea and giving strength to the meaning as well as adding beauty, especially in the Quran, but the situation is different in English. So such repetition may weaken the meaning of the English version.

\subsection{The fourth aspect: the use of ancient words and Biblical terms}

Although Arberry mentioned in the introduction, that he avoided using the slang and unmannered English language so as to avoid ancient biblical terms of his predecessors. But he still mixed modern and old language by including some ancient words in his translation, scattered here and there; so that the translation might add a bit of fluency and privacy, to make the translated text look different and unlike other text, but to look religious and more sacrosanct. But this may be considered a defect in modern translation, because these old words are no longer used in modern English and many of the English speakers cannot understand them in their Quranic context, as well as the users of this translation to whom English is a foreign language.

So the use of old words and expressions constituted a major weakness in Arberry's translation. The ancient words used by Arberry included functional words such as pronouns and old plural nouns such as:(thou, thy, thine, thee, aught, knowest). He also used ancient words and expressions such as "lo" rather than "behold" or "look" as in his translation of the meaning of the verse:

$$
\text { [فإذا حبالهم و عصيهم يخيل إليه] (طه:60) }
$$

When we read "If their ropes and sticks are seen by him" (Taha: 60). He also made a mistake of (خلوا) as he translated it as (go privily), so this word that did not fit the context of the verse. He also translated the word (اندادا) as (موعد) as (compeers), and the word) but this translation is incorrect because the meaning of (tryst) in the English dictionaries is "a date for meeting the loved ones" so the correct translation was to use (meeting place) for (مو عد).

He also translated the word (chastisement=عذاب) which is an old English word. He should have used a modern word such as (torment). He also tried to avoid the Christian words contained in the Old and New Testament in his translation, as he claimed in his introduction, and therefore he used them in certain cases only, such as the use of the word (Gehenna) as synonymous with the word (hell), which Arberry used only in the sense of fire.

\subsection{Fifth side: Confusion in the meanings of some of the Quranic words}

Although Arberry has exerted great effort to investigate accuracy-but he was confused in the incorrect use of some Quranic words like other Orientalists who studied Arabic, and who tried to translate the meanings of the Quran, but faced with some problems in understanding some concepts and words that are frequently repeated in the Quran. This would lead them to confuse the meanings of words that appeared to be similar to other words in terms of form or meaning: Such examples of this confusion: 


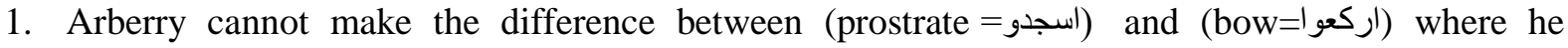
translated:

$$
\text { [و إذ قلنا للملائكة اسجدوا لآدم فسجدو]] (البقرة:34). }
$$

As (And when We said to the angels, 'Bow yourselves to Adam'; so they bowed).

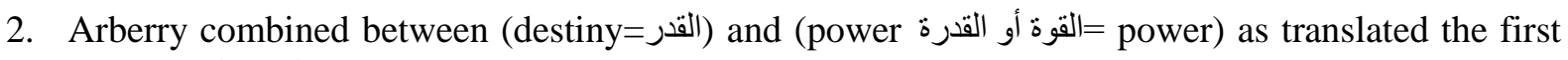
as Surat al-Qadr.

3. He also confused the meaning of (Friday=(يوم الجمعة) as the same as (congregation or group=aماعة) instead of Friday, and between (الئلك) و(المملكة) as he translated the first (Kingdom) and the second as Dominion.

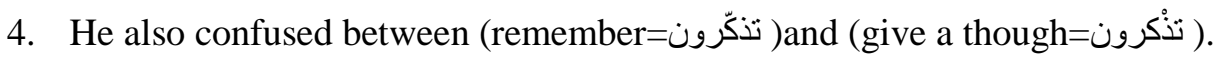

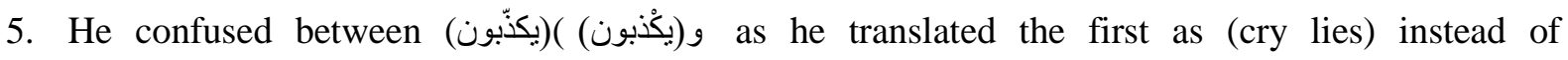
(disbelieve).

6. He makes a confusion between (وليّكم) و(صديقكم) as he translated (وليّم) in verse:

$$
\text { [إنما وليّكم الله ورسوله] (المائدة:55) }
$$

He translated it (Your friend is only God, and His Messenger) instead of saying (Your helper (or protector) is only God).

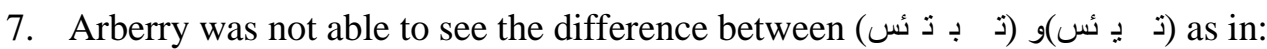

$$
\text { [فلا تبتئس بما كانوا يعملون] (يوسف:69) }
$$

As he translated it as (so do not despair of that they have done) while the correct translation is (so do not grieve of that they have done).

1. He translated the word "Al Furqan" as (Salvation). This word expresses the concept of salvation from sin as it exists in Christianity. Therefore, it may be understood in the sense of "forgiveness" for its similarity to the word "Criterion."

2. Arberry mixed between the (Umrah) and (the visit) so he translated (Umarah) as (visitation). It is literally a literary word meaning (official visit or divine punishment), but this is a false translation. As an English synonym for the word 'Umrah, is absent, he could make a transliteration of the word by using the other language characters. In this case, the translation of the word would be (Umrah), since there is no synonym for the word in English. It is noteworthy that Arberry resorted to the process of transliteration in very limited cases, for example, in (Surat al-Kahf) where he used the word (Errakeem=الرقيم) as well as in the translation of the name of (Surat Al-Hijr), as he transferred the same words into the English as: El-Hijr. This example prompts us to talk about another important aspect of Arberry's translation, and that aspect is his translation of the names of the Suras of the Quran.

\subsection{Sixth side: errors in the names of the Sura}

One of the most striking observations on the Arberry's translation is his lack of understanding of the intended meaning of the names of the Suras in the Holy Qur'an.

First, in terms of the structures of words"Arberry dismissed "the definite-the" in English in some of the names of the Suras while kept it in others, and the names of the Suras-in his translation without

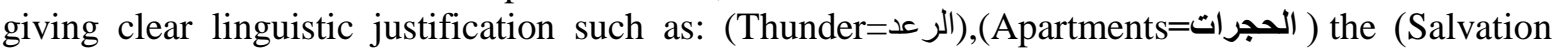

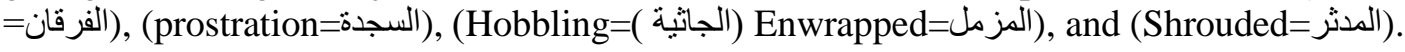

We need to say that all of these Suras refer to proper nouns and not abstract in their meaning, regardless of any particular context. Therefore, according to the general English rule, the translator should have used the definite article (the $)$ with all of these names. But it is not clear why Arberry did not mention or adopted any source for this. Perhaps he might have adopted his own criteria and his personal point of view in this area.

\subsection{Second: in terms of the meanings of the names of the Suras}

In addition to the ambiguity in the grammatical structures of the names of the Suras, Arberry also 
misinterpreted many of the meanings of these words. As we have mentioned above, in addition to his mistakes in the names of surat (Friday=الجمعة) (الملك=), (Dominion (الفرقان), he made (Alfurqan following mistakes:

1. He used the word (The Battlement سورة الأعراف: But when we looked the word up in the (Cambridge Dictionary) we found Battlement is (a wall around the top of a castle, with regular spaces in it through which the people inside the castle can shoot). But this meaning will not fit here. He would better transliterate the word as (al-A'rāf) since there is no synonym in English.

2. He gave the name of (the story) to mean (القصص) and the correct term for that is (The Narration).

3. He also translated the name of (الروم)as (The Greek), Although the translations of Pickthall, Abdullah Yusuf Ali, Halali \& Khan all gathered on the translation of (The Romans), but this is also a common mistake, and the correct translation is (The Byzantines or the Roman) as the Arabs used to call them during the time of the Prophet (peace be upon him).

- (Ghafer: غافر)=(the Believer), it has another name as the (Believer), but Arberry used the plural form (The Believers), which is the name of another sura in the Holy Quran.

- (The Companies الزمر:) but the correct form is (The Throngs).

- (Distinguished فُ فُيّلت ):but according to the name it could have been (the expounded)

- (الجاثية: (The Hobbling. It was better called the (kneeling).

- (الواقعة: (The Terror)but it could be translated as (the inevitable).

- (The Ranks:but it is not the right equivalent. It should have been translated as (the Rank).

- (Afternoon:(العصر) but the correct word is the (Time).

\subsection{The Seventh Side: Translation of idiomatic expression in the Quran}

Arberry was successful in the translation of some Quranic idioms, as we have seen earlier; but he failed to deal with some others. Indeed, it is always a great problem for all translators of the meanings of the Quran from the Arabs and non-Arabs, because of the difficulty of the language of the original text. The problem may be greater for translators who do not speak Arabic because of their inability to understand the meanings of most of the denominations in Arabic. To understand the Quranic verses, one must refer to) references of interpretations (كتب التفاسير) to understand the meaning of the Quranic text.

Therefore, Arberry did not succeed in conveying the meanings of most of the Quranic idioms into English. He may be excused for this. In this aspect, he was like other interpreters of the meanings of the Holy Quran, who were caught in the same mistakes. Some examples are following:

1. The meaning of the verse:

$$
\text { (ويشبت أقدامكم)(محمد:( ) }
$$

He translated it as (And confirm your feet), while the correct is: (and make you steadfast)

2. In the verse:

$$
\text { (واخفض لهما جناح الذل من الرحمة) (الإسر اء:24) }
$$

He translated it as (The lower wing has the humiliation ofmercy), but this is a literal translation while the correct meaning is (And submit yourself to them out of mercy.)

3. In the verse"

$$
\begin{aligned}
& \text { فَارِغًا) } \\
& \text { (وَأَصْبَحَ فُوَاَدُ أُمِّ مُوسَى (القصص:10) }
\end{aligned}
$$

He translated it as (On the morrow the heart of Moses' mother became empty). In addition to the ambiguity in the meaning of "became: اصبح" - as we lhad explained earlier - Arberry overlooked the 
meaning of the metaphor in this verse - that Moses mother was no longer occupied by anything except what she had heard that Moses was under the care of Pharaoh's family. So the correct translation is to say: (And Moses' mother became preoccupied with nothing but Moses).

4. He translated the verse:

تَبْسُطْهَا كُلَّ الْبَسْطِ

$$
\text { وَلاَ تَجْعَلْ يَدَكَ مَغْلُولَةً إِلى عُنْقِكَ وَلاً (الإسر اء:29) }
$$

As (And keep not thy hand chained to thy neck, nor outspread it widespread). This is a literal translation, that changed the correct meaning of the verse, namely, the metaphor of (stinginess) and (spending), so that the translation should be as follows:(And be neither miserly nor extravagant).

5. He translated:

$$
\text { [ظل وجهه مسوداً] (النحل:58) }
$$

As (his face darkened) and the correct meaning is to say: (he becomes disgraced).

6. He made a literal translation for:

$$
\text { [وأشربوا في قلوبهم العجل] (البقر:93) }
$$

As saying (and they were made to drink the calf in their heart).This is a very awkward translation. It shows the difficulty of fully mastering the secrets of the Arabic language in general, and fully understanding the Quranic text. The correct translation for this verse should be as follows: (and their hearts were soaked with the love of the calf).

7. Arberry translated this verse:

$$
\text { [ويوم يعضّ الظالم على يديه] (الفرقان:27) }
$$

As (Upon the day the evildoer shall bite his hands), while the correct translation is (Upon the day the evildoer shall feel remorse).

8. He failed to translate:

$$
\text { [فانبذ إليهم على سواء] (الأنفال:58) }
$$

He translated it as (Dissolve it with them equally). This is a vague translation, especially with the use of the vague reference in the pronoun (it). The correct meaning, as stated in the interpretation (التفسير)is: (To tell them openly that the covenant is no longer valid).

\section{CONCLUSION}

Through the careful and critical survey of the English translation of A.J.Arrbey of the Holy Quran, we can say that this translation is the best English translation made by a non-Muslim, from two main aspects:

Firstly: the position of the translator himself, is clear to us as he was different from the earlier Orientalists to be fair and objective. His work did not only violate the trend of most of the haters of Islam and the Quran, but he defended the Quran by refuting some of the claims and fabrications of his predecessors.

Secondly: his translation-which surpassed some of contemporary Islamic translations of the Quran-has been distinguished in several ways, including its literary language, the sweetness of style, and its accuracy in conveying the meanings of the Holy Quran into English, without deficiency or increment.

It seems that the position of Arberry himself in terms of being free of prejudice of previous negative ideas about the Quran, and his own tasting for the eloquence of the great Book, and its fine rhetoric; all of these factors have been positively reflected on his translation of the Text.

Among the most prominent observations on his translation; was his claim to create rhythmic patterns that mimic what is in the Quran, to appear as a revelation. As we have already mentioned it was one of Arberry's falls. It was clear that he did not intend to offend the Holy Quran, but he was misled by his linguistic ability, and perhaps was driven by his great admiration of the sound rhythm in the Quran to make this claim, which proved a failure.

As we have seen through the examples, there were many observations on Arrbery's translation 
concerning the language, but the translation in general, as compared with other previous translations, had a few errors. Most of the errors were purely linguistic, due to some weaknesses in his Arabic language, as an English speaker, but all his mistakes are adjustable and can be corrected.

What is important is that, his mistakes were not due to confused thinking or certain misconceptions about the Islamic religion, and perhaps the large number of remarks on Arberry, confirms the impossibility of reaching a full translation without errors. The Quran is a miraculous text and its translation is only a mere human effort.

Arberry admitted that the Quran cannot be translated. He tried to imitate the eloquence of the Quran. But he limited his translation to the English text without making explanatory margins or commentaries (which in his view it will distract the magnificence of the Quranic text). He invented, as we have already mentioned, some rhythm that he claimed to have some similarity with the rhythms of the Quranic Text. But he did not succeed in applying this, despite his study of this aspect and his belief that the audio rhythm is one of the most important characteristics of the Quran, which other translators did not realize this importance. In fact this was the challenge of the Quran for the Arabic speakers themselves as the Quran had challenged them to make one similar surah of the Quran, and they failed the test. So it is absolutely impossible for a translation to mimic the music of the Quranic text.

Arrebry's philosophy in the translation of the Quran was to have access to the rich rhetoric of the Quran and to simulate these features in his translation, but this is/was impossible and was not recahed by one of the translators, even Arberry himself, who tried so much.

We must realize that the Quranic text is not like any other text in all languages, because it inspired by God, and therefore it is important to use the appropriate method in the translation of its meanings-just the meaning, to be appropriate to the word of God Almighty. This is what we believe Arberry succeeded to apply to a large extent

The exaggeration in the use of contemporary language is clearly a wrong direction; because it makes the Quranic Text lose its eloquence and beauty, which is at the same time a dangerous orientation that we must fear that we must not to immerse in using slang language or the language of daily communication in the translation of the Quranic Text. But Arberry's attempt to strike a balance between the use of clear contemporary language and the use of literary literalism (sometimes using obsolete terminology) was a very difficult balancing effort. So we believe that, studying this translation in all its aspects is essential and advantageous.

Among the recommendations that can be drawn from this research is the re-printing and the reproducing of Arberry's translation, taking into account all of the above observations and conclusions. Then we can work on correcting the linguistic errors by attaching the necessary explanatory notes or commentaries, and by numbering the verses (because Arberry did not follow the usual numbering system of the suras). We can also try to maintain the level of literary language as much as possible,

Undoubtedly, the study of the errors which the translators make or made is/was very necessary when using comments and explanations to clarify the meanings of the words of the Holy Book, to avoid ambiguity, and to contribute to the development of its translation, in a precise and fluent language. So this translation - after making the necessary adjustments - can play an active role in the field of (Daawa) to Allah, as this translator -in particular-was a non-Muslim Orientalist who had booked a great place among the group of non-Muslim English intellectuals.

There are many factors of attractions and acceptance in Arberry's translation. It is easy for the target reader to understand and enjoy it as well. Perhaps the King Fahd Complex for the Printing and publication of the Holy Quran is the best organization that can be entrusted to do this work and to take care of the Book and serve it, by all means and possibilities. I need to recommend this Organization to study Arberry's translation and give it special care. Such work can be done by committees assigned to study this translation and prepare a comprehensive report by specialists and researchers. Then, based on the recommendation of these committees, a new version of Arrbery's translation can be issued to serve Muslims and non-Muslims in various parts of the earth.

\section{ARABIC REVERENCES}

$$
\text { 1. ابن كثير : مختصر تفسير /بن كثير ، اختصار وتحقيق: محمد عل ي الصابوني. (بيروت: دار القرآن الكريم، الطبعة }
$$




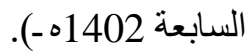

$$
\begin{aligned}
& \text { 2. الأشقر، محمد سليمان عبد الله : نفحة العبير من زبدة التفسبر (الرياض: دار السلام للنشر و التوزيع، 1417ه ـ - } \\
& \text {.) 1996 } \\
& \text { 3. عبد الرحمن، وجيه حمد : "وقفة مع بعض الترجمات الإنجليزية لمعاني القرآن الكريم." بوثوث ندوة عناية المملكة }
\end{aligned}
$$

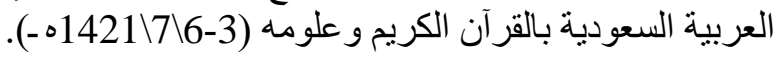

\section{REFERENCES}

[1] Abdulrahman, Wajih. "Reflections on the Translation of Quranic Idioms." Turjuman, 6 (1) 1997: 5767.

[2] Al-Hilali, Mohammad T., and Khan, Mohammad M, Translation of the Meanings of the Noble Qur'an. (Madinah Munawwarah: King Fahd Complex for the Printing of the Holy Qur'an).

[3] Ali, Abdullah Yusuf. The Meanings of the Holy Quran.

a. (Brentwood (Maryland): Amana Corp, 1992).

[4] Arberry Arthur, The Koran Interpreted, (Oxford: Oxford UP, 1964).

[5] ------------ The Holy Koran: An Introduction with Selections, (London: George Allen and Unwin Ltd, 1953).

[6] Hosni, Abdul Moneim, "On Translating the Quran: (An Introductory essay)". Journal of King Saud U. vol 2, Arts 2: 1990, 93-134.

[7] Pickthall, Marmaduke, The Glorious Quran. (Istanbul, 1999).

a. Oueijan, Naji, The Progress of an image: the East in English Literature, (New York: Peter Lang, 1996).

[8] Watt, W. Montgomery, Companion to the Quran: Based on the Arberry Translation, (London: George Allen and Unwin Ltd, 1967).

${ }^{(*)}$ This is a translation of a paper entitled:

دراسة لترجمة معانى القرآن الكريم إلى الإنجليزية(القرآن مترجما) للمستشرق الإنجليزي آرثر ج. آربري

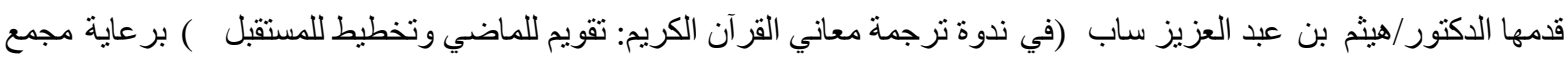

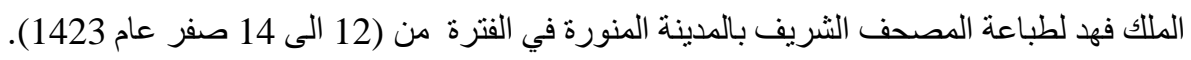

\section{AUTHOR'S BIOGRAPHY}

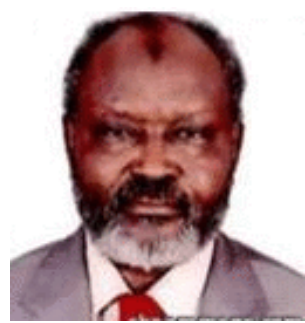

Dr. Ahmed Gumaa Siddiek, got his B.A in English with (MERIT) from Khartoum University in (1982). He has an MA in Translation from the Islamic Institute for Translation in Khartoum as well as an M.Ed in (TEFL) from Juba University-Sudan (2002). He had his Ph.D with (EXCELLENT) in (Language Testing)) in (2004) from Omdurman Islamic University-Sudan. Since then Dr. Siddiek has been lecturing in Sudan and Saudi Arabia. He has published widely in ELT journals in USA, UK, Canada, Finland, Australia and India. He attended conferences and read papers in Harvard and Purdue, in USA. His papers were also accepted for conferences in Germany, France and Canada. Dr. Siddiek is the Author of: (Assessment of the Sudan School Certificate English Examinations) \& (Language Challenges in Post-War Sudan). Dr. Siddiek is a member of editorial Boards of many ELT journals in Canada, USA and Australia.

Citation: Ahmed Gumaa Siddeik. "A Critical Reading of A. J. Arberry's Translation (*) of the Meanings of the Holy Quran (Koran Translated) "International Journal on Studies in English Language and Literature (IJSELL), vol 6, no. 5, 2018, pp. 46-62. doi:http://dx.doi.org/10.20431/2347-3134.0605007.

Copyright: () 2018 Authors. This is an open-access article distributed under the terms of the Creative Commons Attribution License, which permits unrestricted use, distribution, and reproduction in any medium, provided the original author and source are credited. 